\title{
VIGOTSKI, LEV SEMIONOVITCH. IMAGINAÇÃO E CRIAÇÃO NA InfÂnCIA. SÃo PAUlo: EXPRESSÃo PoPUlar, 2018.
}

\author{
Maurício Pedro da Silva \\ Doutor em Literatura Brasileira \\ Universidade de São Paulo - USP. \\ São Paulo, SP - Brasil. \\ maurisil@gmail.com \\ Vanessa Leão Franchi Ferreira \\ Mestranda em Educação \\ Universidade Nove de Julho - Uninove. \\ São Paulo, SP - Brasil. \\ vanessa.leao88@hotmail.com
}

\section{Para citar-ABNT NBR 6023:2018}

SILVA, Maurício Pedro da; FERREIRA, Vanessa Leão Franchi. Resenha. Cadernos de Pós-graduação, São Paulo, v. 20, n. 1, p. 294-296, jan./jun. 2021. Resenha da obra de VIGOTSKI, Lev Semionovitch. Imaginação e criação na infância. São Paulo: expressão popular, 2018. Disponível em: https://doi.org/10.5585/cpg.v20n1.18798.

Lev Semionovitch Vigotski nasceu em Orsha, uma cidade do Bielorússia, em 1896, e faleceu na capital da Rússia, Moscou, em 1934. Nestes 38 anos de vida, estudou Direito, Literatura e História da Arte, dedicando-se, paralelamente, à Psicologia, área em que se tornou um nome proeminente, passando então a se dedicar à área, aos estudos, pesquisas e cursos sobre Psicologia. Além disso, dedicou-se à pesquisa do desenvolvimento da consciência humana, bem como, da aquisição e desenvolvimento da linguagem. A formação social da mente e Pensamento e Linguagem são duas de suas obras mais conhecidas na área da Educação e da Psicologia.

O presente livro, Imaginação e Criação na Infância, aborda a questão da imaginação, seus conceitos e sua formação na infância e versa também sobre a criação literária, teatral e do desenho. Nesta obra, Vigotski define quatro formas principais de relação entre a atividade de imaginação e a realidade.

A primeira forma consiste na ideia de que a imaginação apoia-se sempre em elementos da realidade e experiências vividas pela pessoa. Mesmo construções mais fantasiosas, como podemos encontrar nos contos, mitos, lendas e sonhos, por exemplo, são submetidas aos elementos da realidade, modificados na nossa imaginação: "A atividade criadora da imaginação depende diretamente da riqueza e da diversidade da experiência anterior da pessoa porque essa experiência constitui o material com que se criam as construções da fantasia" (p. 24). 
A segunda forma de relação entre fantasia e realidade está pautada no inverso da primeira forma, ou seja, pode-se dizer que a experiência real que se apoia na imaginação. Dessa forma, podese concluir que, ao criarmos, por exemplo, uma narrativa fantástica, teremos de buscar elementos de nossa imaginação para compô-la: "A pessoa não se restringe ao círculo e a limites estreitos de sua experiência, mas pode aventurar-se para além deles, assimilando a experiência histórica ou social alheias com a ajuda da imaginação" (p. 27).

Por outro lado, a terceira forma - que o autor define como a lei da realidade emocional trabalha com o caráter emocional, baseando-se na influência que esse fator tem sobre a fantasia. Podemos observar que, ao contemplarmos uma pintura, tanto suas cores quanto as expressões das personagens, essa pintura pode causar-nos espanto e tristeza ou alegria e contentamento, dependendo das cores e expressões utilizadas pelo pintor, pois exercem influência direta em nossas emoções: "As paixões e os destinos de heróis inventados, sua alegria e desgraça, perturbam-nos, inquietam-nos e contagiam-nos, apesar de estarmos diante de acontecimentos inverídicos, de invenções da fantasia" (p. 30).

Finalmente, a quarta forma demonstra que a construção da fantasia pode tornar-se realidade - sendo assim, uma pessoa pode usar de sua imaginação e fantasia para construir uma máquina ou um instrumento nunca antes conhecido; Vigotski define essa forma como imaginação cristalizada ou encarnada.

$\mathrm{Na}$ sequência de suas considerações, o autor relata como a criação literária na idade escolar se desenvolve, partindo da ideia de que, no período da pré-escola, a criança se expressa com mais facilidade, por meio do ato de desenhar, como algo espontâneo e criativo, porém, com o passar dos anos, esse interesse vai se enfraquecendo e muitas delas perdem por completo a vontade de desenhar. No período escolar, a criança vai tomando contato com outras formas de expressão, como a criação literária (a escrita), sendo que o desenho passa a ser desestimulado.

Vygotski trata também da criação teatral na idade escolar, destacando a importância do ato de encenar e de dramatizar, pois, por meio dele, a criança é estimulada a brincar, criar, improvisar, preparar, desenhar etc. tudo quanto ela precisar para a apresentação de sua cena, fortalecendo diretamente a imaginação. Entretanto, Vigotski afirma que essa criação teatral deve ser realizada e estimulada de forma espontânea e não impositiva, de maneira que as crianças não sejam meros transmissores de palavras de outrem, atividade desestimulante e pouco criativa.

No último capítulo do livro, o autor detalha dados sobre quando a criança perde o interesse em desenhar e quando o adquire novamente, em alguns casos; demonstra idades e pesquisas a esse respeito e disponibiliza, em anexo, desenhos de crianças de diferentes faixas etárias, em diversas circunstâncias e experiências de vida. Por fim, Vigotski ratifica a importância do estímulo à criação 
e à imaginação durante a vida escolar da criança, pois tais estímulos auxiliarão, de forma bastante positiva, na tomada de decisões, na forma de enxergar o outro e nas situações a sua volta, ao longo de toda a vida.

Diante de todos esses conceitos, podemos refletir o quanto o processo educacional a que uma criança estará submetida durante grande parte de sua vida pode ou não contribuir para a formação de uma pessoa, com riqueza de saberes, de estímulos, vivências e experiências, sendo que, dessa forma, todos esses aprendizados vão compor a integralidade do ser.

O livro de Vygotski contribui, com certeza, para essa tomada de consciência e para que aprendamos mais acerca da importância da imaginação e da criação nos primeiros anos de vida da criança. 